\title{
Beş Faktör Kişilik Özelliklerinin Hedonik Tüketim Üzerine Etkisinin İncelenmesi (Investigation of the Effect of Five Factor Personality Traits on Hedonic Consumption)
}

\author{
Ali SOLUNOĞLU iD a Aylin NALÇACI İKİZ iD \\ a Kırıkkale Üniversitesi, Fatma Şenses Sosyal Bilimler MYO, Kırıkkale, Türkiye. alisolunoglu@msn.com \\ b Kırıkkale Üniversitesi, Fatma Şenses Sosyal Bilimler MYO, Kırıkkale, Türkiye. a.nalcaci@yandex.com
}

\begin{tabular}{l}
\hline MAKALE BİLGİṡ \\
\hline Anahtar Kelimeler: \\
Beş Faktör Kişilik Özellikleri \\
Hedonik Tüketim \\
Tüketici Davranışı \\
\\
Gönderilme Tarihi 21 Nisan \\
2020 \\
Revizyon Tarihi 3 Temmuz \\
2020
\end{tabular}

Kabul Tarihi 10 Temmuz 2020

\section{ÖZET}

Amaç - Bu çalışmanın amacı, tüketicilerin kişilik özelliklerinin belirlenerek hedonik tüketim üzerindeki etkisini anlamak ve çok boyutlu yapısını incelemektir. Literatürde tüketim ve tüketici davranışları ile ilgili araştırmalarda kişilik özelliklerini konu edinen araştırmalara rastlansa da bu çalışmalarda tüketimin A ve B tipi kişiliği ilişkilendirdiği ya da araştırmaların plansız, içgüdüsel satın alma üzerine odaklandığı görülmektedir. Bu anlamda çalışma, beş faktör kişilik özelliklerinin hedonik tüketim üzerine etkisinin incelenmesi açısından önemlidir.

Yöntem - Çalışmada Beş Faktör Kişilik Envanteri ve hedonik tüketim ölçeği kullanılmış ve böylece kişilik tiplerinin hedonik tüketimin alt boyutlarına etkileri belirlenmeye çalışılmışır. Araştırma, 2019 yılının Mayıs-Eylül ayları arasında Ankara ilinin en kalabalık ilçesi olan Çankaya'da bulunan iki alışveriş merkezinde anket uygulaması şeklinde yürütülmüştür. Araştırma katılımcıları, gönüllülük esasıyla araştırmaya katılan, 18 yaş üstü, satın alma gücü olduğunu beyan eden 370 kişiden oluşmaktadır. İncelenen literatür doğrultusunda, tüketicilerin alışverişlerinde hedonik güdülerin faydacı güdülerden ziyade baskın olduğu ve zevk almak için tüketim yaptıkları varsayımı ile hareket edilmiştir. Bu nedenle, özellikle bir ürün grubu belirtilmemiş ve genel tüketim davranışlarını analiz etmek için son alışveriş deneyimleri dikkate alınmıştır.

Bulgular - Elde edilen bulgular tüketicilerin kişilik tiplerinin hedonik tüketim boyutları üzerinde çeşitli düzeylerde etkisi bulunduğunu göstermektedir. Özellikle dışa dönük kişilik özelliğinin, hedonik tüketimin birden fazla alt boyutu üzerinde etkisi olduğu bulunmuştur.

Makale Kategorisi:

Araştırma Makalesi

Tartışma - Bu araştırmadan elde edilen sonuçlar, hedonik güdüler ile alışveriş yapan tüketicilerin kişilik özelliklerinin doğru şekilde belirlenmesinin ve buna yönelik olarak pazarlama karması elemanlarının belirlemesinin işletmelere rekabetçi avantaj sağlayabileceğini göstermektedir.

\begin{tabular}{l}
\hline ARTICLE INFO \\
\hline Keywords: \\
Five Factor Personality Traits \\
Hedonic Consumption \\
Consumer Behavior
\end{tabular}

ABSTRACT

Purpose - The aim of this study is to determine the personality traits of consumers and to understand the effect of hedonic consumption and to examine its multi-dimensional structure. In the literature, there are studies on the subject of personality traits in researches related to consumption and consumer behavior. However, in these studies, it is seen that consumption associates A and B personality or focuses on unplanned, impulse purchasing. In this sense, the study is important in terms of examining the effect of five-factor personality traits on hedonic consumption.

Design/methodology/approach - In this study, Five Factor Personality Inventory and hedonic Received 21 April 2020

Revised 3 July 2020 consumption scale were used, and thus, the effects of personality types on the sub-dimensions of hedonic consumption were tried to be determined. The research was carried out in the form of a questionnaire in two shopping centers in Çankaya, the most populous district of Ankara, between May and September 2019. The research participants consisted of 370 people over the age of 18 who declared that they had purchasing power. In line with the literature examined, it was acted with the assumption that hedonic motives predominate rather than utilitarian motives in consumers' shopping and that they make consumption to enjoy. For this reason, especially a product group is not specified, and recent shopping experiences are considered in order to analyze general consumption behaviors.

Findings - The findings show that the personality types of consumers have various effects on hedonic consumption dimensions. Especially the extroverted personality trait has been found to have an effect on more than one sub-dimension of hedonic consumption.

Discussion - The results obtained from this research show that the correct determination of the personality traits of the consumers who shop with hedonic motives and the determination of the marketing mix elements for this purpose can provide a competitive advantage to the enterprises. 


\section{GİRIŞ}

İkinci dünya savaşından sonra toplumların ekonomik, sosyal ve kültürel yapılarında önemli dönüşümler yaşanmıştır. Kültürel yapıyı oluşturan önemli unsurlardan biri olan tüketim olgusu da bu değişimlerin etkisi ile yeniden tanımlanmaya başlanmış ve özellikle 1960'lardan itibaren oluşmaya başlayan postmodern koşullar, üretim toplumundan tüketim toplumuna geçişe zemin hazırlamıştır. Artık tüketim, toplumsal hayatın merkezinde yer almakta ve bireylerin kimliklerini belirleyerek toplumsal ilişkileri düzenlemektedir. İhtiyacı için tüketen modern insan, tüketimi teşvik eden, tüketimin gerçekleşmesi için sürekli yeni alternatifler üreten postmodern anlayışıyla artık haz almak için ürünlerin gerçek değerlerinden ziyade sembolik değerlerine odaklanarak tüketim eylemini gerçekleştirmektedir. Tüketim, haz alma isteği ve arzuları tatmin duygusu ile hedonist bir yapıya kavuşmuştur. Böylece Eski Yunanda bir felsefi öğreti olarak ortaya çıkan hedonizm, değişen tüketim alışkanlıkları ile günümüzde pazarlama alanında yapılan tüketim araştırmalarında kendinden sıkça söz ettirmeye başlamıştır.

Kişilik, insan davranışlarına yön veren önemli etmenlerden biridir. Tüketim açısından değerlendirildiğinde, bireylerin kişiliklerinin doğru şekilde analiz edilmesi tüketim alışkanlıklarının ve satın alma davranışlarının nedenlerinin ortaya konması açısından önemli bilgiler sağlayacaktır. Tüketimde hedonizmin derecesi kişilere ve toplumlara göre değişiklik gösterebilmektedir (Türk, 2018: 856). Bu nedenle bireylerin kişilik özelliklerinin bilinmesi onların hedonik tüketim eğilimlerinin belirlenmesi açısından önemlidir.

$\mathrm{Bu}$ araştırma farklı kişilik özelliklerinin hedonik tüketim üzerindeki etkisinin incelenmesi amacıyla hazırlanmıştır. Literatürde tüketim ve tüketici davranışları ile ilgili araştırmalarda kişilik özelliklerini konu edinen araştırmalara rastlansa da (Goldsmith, 2016; Guido, 2006; Deniz ve Erciş, 2010) araştırmalarda tüketimin A ve B tipi kişiliği ilişkilendirdiği ya da araştırmaların plansız, içgüdüsel satın alma üzerine odaklandığı görülmektedir. Bu çalışma hedonik tüketim boyutlarını beş faktör kişilik özellikleri açısından ele aldığı için literatüre katkı sağlayacağı düşünülmektedir.

\section{KAVRAMSAL ÇERÇEVE}

\subsection{Hedonizm}

Hazzı, yaşamın anlamı ve en yüksek değer olarak gören hedonizm, Yunanca "zevk, haz" anlamlarına gelen "hedone" kelimesinden doğmuştur. Hedonizm temelinde "insan mutluluğa nasıl erişebilir?" sorusunu içeren felsefi bir görüştür. Bu felsefi görüş, M.Ö 435-336 yılları arasında yaşayan, Sokrates'in öğrencisi ve aynı zamanda Kirene Okulunun kurucusu olan Aristippos tarafından ortaya atılmıştır. Aristippos'a göre yaşamın tek amacı ve erdemin tek şartı hazza ulaşmaktır. (Yıldız Turan, 2015: 251). İnsan acı veren durumlardan kaçınmalı ve en iyi olan hazza ulaşmalıdır. Haz mutluluktur ve hayatın amacı en iyiye ulaşmaktır (Sönmez, 2014: 10).

Hedonizm dendiğinde akla ilk gelen isimlerden bir diğeri de Epiküros'tur. Epiküros hazzı Aristippos'tan farklı yorumlamış bedensel hazdan ziyade ruhani hazzın önemine vurgu yapmıştır. Epiküros, hazzın iyi olduğunu fakat haz elde etmek için çekilecek sıkıntıların da acı vereceğini belirtmiştir. Epikuros'a göre sonunda acı olan haz insanı mutlu etmez, insan acıdan ve sıkıntıdan kaçındıkça mutlu olabilir (Arı, 2012: 3).

\subsubsection{Hedonik Tüketim}

M.Ö. 4. ve 5.yüzyılda felsefi bir öğreti olarak ortaya çıkan hedonizmin tüketim boyutunda kendine yer bulması, 18 yüzyılda kapitalizmin toplumsal ahlak ve değer yargılarını etkilediği döneme rastlamaktadır (Odabaşı, 2017: 115). Yeni üretim güçlerinin var olduğu ve tüketimin gittikçe artarak ihtiyaçtan isteğe döndüğü (Hatipler, 2017: 1) bu dönem "tüketim toplumu" kavramının belirginleştiği dönemdir.

Tüketim, Bauman (1997) tarafından postmodern sürecin bir ürünü olarak ifade edilmektedir (akt. Özcan, 2011: 142). Bu dönemde tüketimi temel ihtiyaçlarını karşılamak yerine kimlik oluşturmak, toplumda saygın bir yer edinmek için yapan postmodern bireyler ortaya çıkmıştır. İnsan hayatının merkezinde bir eylem olan tüketim, zorunlu ihtiyaçların giderilmesi amacıyla ürünlerin faydasına odaklanılarak yapılırken, postmodernizm etkisiyle normal bir tavır olmaktan çıkmış (Osmanlı ve Kaya, 2014: 11) ve haz ve mutluluk almak, psikolojik tatmin yaşamak amacıyla yapılmaya başlanmıştır. Tüketiciler ürünlerin temel işlevlerinden ziyade o üründen elde edecekleri psikolojik ve sosyolojik tatmine odaklanmıştır. Hedonik (hazcı) tüketim olarak adlandırılan ve "tüketim deneyiminin çok boyutlu, fantazi ve duygusal yönleriyle ilgili olan tüketici davranışı biçimleri" 


\section{A. Solunoğlu - A. Nalçacı İkiz 12/3 (2020) 2344-2361}

(Hirschman ve Holbrook, 1982: 92) olarak tanımlanan bu kavram giderek önemini arttırmış ve çeşitli disiplinlerde araştırma konusu haline gelmiştir.

Tüketimi inceleyen geleneksel araştırmalarda tüketimin faydacı, rasyonel değerine odaklanılmıştır. Faydacı değer, satın alma olayını başarılması gereken bir iş, tamamlanması gereken bir görev olarak görmekte ve ürünlerin işlevsel ve fiziksel özelliklerine yoğunlaşmaktadırlar. Faydacı değer, insanların bir ürüne ihtiyaç duymaları halinde, o ürünün verimli ve bilinçli satın almasıyla ortaya çıkmaktadır (Babin, Darden ve Griffin, 1994: 645). Tüketimi inceleyen modern çalışmalarda ise değer konusu biraz daha karmaşıklaşmaktadır. Bu araştırmalar modern tüketicinin sadece akılcı, faydacı alışveriş yapmadığını (Odabaşı, 2017: 118), duygusal anlamda haz duyabilecekleri, eğlenebilecekleri ve keyif alabilecekleri alışverişler de yaptıklarını göstermektedir (Doğrul, 2012: 324). Çünkü tüketim davranışının temelinde faydacı ve hedonik olmak üzere iki tür değer söz konusudur. Geleneksel araştırmaların göz ardı ettiği boyut da, tüketim deneyimi ile ilgili olan hedonik değerlerdir (Hirschman ve Holbrook, 1982: 138). Hedonik değerde, tüketimin deneyimsel ve duygusal yönü söz konusudur (Doğrul, 2012: 325). İnsanlar tüketimi zevk almak ve haz elde etmek için yapmaktadırlar (Fettahlıŏglu, Yıldız ve Birin, 2014: 309). Tüketicinin sağladığı hedonik değer, faydacı değere kıyasla daha eğlenceli ve kişiseldir. Hedonik tüketimde görev tamamlama değil, tüketimden zevk alma, heyecan duyma vardır.

Felsefi olarak hazzı ulaşılması gereken en yüksek değer olarak kabul eden hedonizm, psikolojik olarak güdülenme ile açılanmaktadır. Arnold ve Reynolds (2003) çalışmalarında insanları alışverişe iten hedonik tüketim güdülerini altı kategoride incelemiştir.

1. Macera Alışverişi: Hedonik güdülerin ilki "macera alışverişi" olarak adlandırılmıştır. Arnold ve Reynolds'ın (2003) araştırmasına katılan tüketicilerin önemli bir kısmı, alışverişe tamamen heyecan yaşamak, başka bir dünyada olma hissini tatmak ve macera aramak için gitmektedirler. Katılımcılar, alışveriş deneyimini macera, heyecan, harekete geçme, uyarılma, kokular ve seslerden oluşan farklı bir evrene girme olarak tanımlamıştır.

2.Sosyal Alışveriş: İkinci kategori "sosyal alışveriş "olarak isimlendirilmekte ve insanların alışveriş yaparken çevresindeki insanlarla kurduğu sosyal bağlarla açıklanmaktadır. İnsanlar alışverişi arkadaşları ve aileleri ile zaman geçirmenin bir yolu olarak görmekte ve alışveriş esnasında başkaları ile iletişimde olmanın keyfini yaşamaktadırlar.

3. Değer Alışverişi: Üçüncü kategoride yer alan "değer alışverişi” olarak isimlendirilmiştir. İnsanlar alışverişte pazarlık yapmakta ve indirim aramaktadırlar. Eğer istediklerini elde ederlerse başarma duygusu hissetmekte ve alışverişten zevk ve keyif almaktadırlar. İnsanlar alışverişe bir meydan okuma ya da kazanılacak bir oyun gözüyle bakmaktadırlar.

4. Fikir Alışverişi: Dördüncü kategori, trendler hakkında bilgi edinme ve yeni modaları takip etmek ve yeni ürünleri ve yenilikleri görmek için yapılan alışverişleri içermekte ve "fikir alışverişi" olarak adlandırılmaktadır. İnsanlar satın alma ihtiyacından ziyade bilgi toplama ve fikir edinme amacı ile alışverişe çıkmaktadırlar.

5. Rol Alışverişi (Başkalarını Mutlu Etme Amaçlı): Beşinci kategoriyi oluşturan "rol alışverişi", kişilerin başkaları için alışveriş yaptıklarında elde ettikleri hazzı ve keyfi açıklamaktadır. İnsanlar için ailelerine, arkadaşlarına ve sevdikleri kişilere hediye almak mutluluk verici ve önemli bir olaydır. Başkaları için hediye almak insanlara kendini iyi hissettirmekte ve olumlu duygular yaşatmaktadır.

6. Rahatlama Alışverişi: Son kategori "rahatlama alışverişi" stres gibi olumsuz duygulardan arınmak için yapılan alışverişlerdir. İnsanlar alışverişi sorunlarını unutmak için kendileri için yaptıkları özel muamele bir nevi tedavi olarak görmektedirler.

Yukarıda açklanan hedonik tüketim güdülerinin etki derecesi bireyden bireye değişiklik gösterebilmektedir. Bu durum hedonizmin öznellik özelliği ile de doğrudan bağlantılıdır. Çünkü "iyi" kavramını her birey kendince tanımlamaktadır (Yücedağ, 2005: 58). Ayrıca bu değişiklik, bireylerin yaşadıkları toplumun, içinde bulundukları durumun ya da bireylerin kişilik özelliklerinin farklılığından kaynaklanabilmektedir. 


\subsection{Kişilik}

Latince "persona" kelimesinden ortaya çıkan ve Batı dillerinde personality, personalität ve personnalité, personality olarak kullanılan "kişilik" kavramının literatürde birçok tanımının olmasının nedeni hala psikologların ve araştırmacıların üzerinde anlaştı̆̆ tek bir tanımının bulunmamasıdır (Cüceloğlu, 1999: 404). Cüceloğlu, (1999) kişiliği "bireyin iç ve dış çevresiyle kurduğu, diğer bireylerden ayırt edici, tutarlı ve yapılaşmış ilişki biçimi" olarak tanımlarken, Burger (2006), "bireyin kendisinden kaynaklanan tutarlı davranış kalıpları kişilik içi süreçler" şeklinde tanımlamaktadır. Larsen ve Buss, (2010) ise kişiliği, "nispeten kalıcı olan, bireyin sosyal ve fiziksel çevreye uyumunu ve karşılıklı iletişimini etkileyen psikolojik özelliklerinin kümesi" olarak tanımlamaktadır.

Kişiliğin yapısını anlama ve kişilikler arası farklılıkların nedenleri ortaya koyabilmek için birçok kuram geliştirilmiştir. Bu kuramlar arasında en çok tartışılanı Sigmund Freud'un psikanalitik kuramıdır ve diğer kuramlar genellikle psikanalitik kurama bir tepki, eleştiri ya da bu kuramın eksik taraflarını tamamlamak üzere ortaya çıkmıştır. Kişilik kuramlarının diğerleri Ayırıcı Özellik Kuramı, Biyolojik Kuram, İnsancıl Kuram, Davranışsal Kuram, Sosyal Öğrenme Kuramı ve Bilişsel Kuramdır. Bu kuramların her biri kişiliği oluşturan farklı kaynaklar üzerinde durmaktadır. Örneğin Freud'un psikanalitik kuramı kişilikten "bilinçaltını" sorumlu tutarken, biyolojik kuram kişiliğin gelişimini "kalıtsal faktörlere" bağlamaktadır. Burger (2006), her kuramın kişiliğin belirli yönlerini açılamak için faydalı olduğunu fakat hiçbir kuramın diğerleri olmadan kişiliği açıklamak için yeterli olmadığını ifade etmektedir.

Kuramlar içinde Ayırıcı Özellikler Kuramı, kuramsal bir yapıdan ziyade araştırma odaklı olduğu için farklı bir yere sahiptir. Bu kuram, kişilik özelliklerinin kararlılık göstererek aynı kaldığını, uzun vadede değişmediğini varsaymaktadır (Burger, 2006: 235). Ayırıcı Özellikler kuramının temsilcileri olan Gordon Allport, Henry Murray ve Raymond B. Cattell kişiliği anlamaya ve sınıflandırmaya yönelik klinik gözlemlerin yerine araştırma odaklı bir yaklaşımı tercih etmişlerdir (Gürel, 2011: 116). Araştırmalarından elde ettikleri bulguları sayısallaştırarak somutlaştırmaya çalışmış (Girgin, 2007: 71) ve bunun sonucunda kişiliği sınıflandırabilmek adına ölçme ve değerlendirme araçları geliştirilmişlerdir. Ayırıcı özellikler kuramına yapılan temel eleştiri, kişilik testlerinden alınan puanlarının davranışları açıklamada yeterli olamayacağı şeklindedir. Fakat bireyler arası karşılaştırma imkânı sunması ve bireysel farklılıkları belirlemesi açısından diğer kuramlar arasında bu kuram hala farklılığını ve gücünü korumaktadır.

\subsubsection{Kişilik Tipleri}

Psikologlar ve araştırmacılar, kişilik farklılıklarını belirlemek ve bireyleri birbirinden ayıran özellikleri ortaya koyabilmek adına gözlem yöntemini, kişilik envanterlerini ve projektif teknikleri kullanmaktadır. Kişilik envanterlerinden biri olan Beş Faktörlü Kişilik Envanteri ya da bir diğer adıyla "Büyük Beşli" üzerine yapılan araştırmalarda tutarlı bulgular üretmesi ve kişiliği açıklamada evrensel olarak genellenebilirlik sağlaması bakımından günümüzde en fazla kullanılan kişilik testlerindendir. Beş faktörlü kişilik envanteri kişiliği beş farklı boyut olarak sınıflandırmaktadır. Bunlar, dışadönüklük, deneyime açıklık, uyumluluk, sorumluluk ve nevrotiklik boyutlarıdır.

1. Dışadönüklük: Dışadönük olarak sınıflandırılan bireyler, girişken, sosyal, cana yakın, maceracı ve konuşkan özelliklere sahiptirler. Bu bireyler insanlarla kolayca iletişime geçebilen, dış dünyaya açık bireylerdir. Dişadönüklük boyutunun diğer ucunu içedönüklük oluşturmaktadır (Somer, Korkmaz ve Tatar, 2002: 23).

2.Deneyime Açıklık: Deneyime açıklık kişilik özelliğine sahip bireyler, bağımsız ve meraklıdırlar. Yeni görüşlere ve deneyimlere açık, hayal gücü yüksek kişiler bu boyutta yer almaktadır. Daha geleneksel ve yenilikten çok bilineni tercih eden, değişime direnen bireyler ise deneyime açılık boyutunun diğer ucunda yer almaktadır (Burger, 2001: 254).

3. Uyumluluk: Uyumluluk boyutunda yüksek puana sahip bireyler, iyi huylu, işbirliğine yatkın ve güvenilir olarak tanımlanmaktadır (John ve Srivastava, 1999: 6). Bu boyuttan düşük puana sahip bireyler ise uyumsuz olarak tanımlanmakta ve bencil, rekabetçi ve kaba özellikler göstermektedirler.

4. Sorumluluk: Sorumluluk boyutu bireylerin disiplinli, düzenli ve dikkatli olma özellikleri ile ilgilidir. Sorumlu bireyler, planlı, tertipli, verimli ve kararlı özellikler gösterirken, sorumsuz bireyler, dikkatsiz, güven vermeyen ve umursamaz davranışlar sergilemektedir (Goldberg, 1992: 33). 


\section{A. Solunoğlu - A. Nalçacı İkiz 12/3 (2020) 2344-2361}

5. Nevrotiklik: Nevrotiklik boyutu bireylerin duygusal tutarsızlıkları ile açıklanmaktadır. Aşırı duygusal değişimler yaşayan, olaylar karşısında olumsuz duygulara kapılan bireylerin nevrotiklik boyutunda puanları yüksek olmaktadır (John ve Srivastava, 1999: 30). Bu boyutta düşük puan alan bireyler ise, duygusal olarak tutarlı kontrollü ve daha az stres yaşayan bireylerdir.

İnsan davranışlarını etkileyen önemli unsurlardan biri olan kişilik, sahip olduğu boyutlar itibariyle de satın alma davranışlarını yönlendirebilmektedir. Hazırlanan bu çalışmada kişilik tipleri ile hedonik tüketim arasındaki ilişki tespit edilerek bu ilişkinin yönü analiz edilmeye çalışılmıştır.

\section{YÖNTEM}

\subsection{Araştırmanın Önemi ve Amacı}

Tüketici memnuniyeti, son yıllarda işletmelerin özellikle üzerinde durdukları bir kavram haline gelmiştir. Çünkü rekabet ortamında işletmeler için tüketici memnuniyeti, devamlı müşteriler, başarılı ve sürekli bir işletme anlamına gelmektedir. Bu memnuniyetin sağlanması tüketici profilinin doğru değerlendirilmesine, tüketicilerle ortak değerler oluşturmaya ve tüketici davranışlarının iyi analiz edilmesine bağlıdır. Potansiyel tüketicileri satın almaya iten faktörlerin belirlenmesi işletmeler için doğru pazarlama stratejilerin seçilmesini ve böylece kaynaklarının verimli şekilde kullanılabilmesini sağlayacaktır.

Tüketici satın alma davranışları ile ilgili araştırmalarda tüketicilerin sadece faydacı ve rasyonel beklentiler içerisinde alışveriş yapmadıkları, haz odaklı sonuçlarla da motive edilebildikleri ortaya konulmuştur (Babin, Darden, ve Griffin,1994). Hatta bazı araştırmalar tüketim eyleminde hedonik, haz odaklı yönlerin rasyonel ve faydacı olanlara göre öncelikli olduğunu savunmaktadır (Avello, Gavilán, Blasco ve Abril, 2010: 131). Postmodern dönemlerde hedonik değerlere odaklanan yeni tüketim kalıpları ortaya çıkmasıyla birlikte işletmelerin tüketim deneyimden haz almaya odaklanan tüketicilerin özelliklerini ve farklılıklarını doğru bir şekilde çözümleyebilmesi rekabette üstünlük sağlayabilmeleri açısından önem taşımaktadır.

Tüketicilerin satın alma kararlarını etkileyen önemli faktörlerden biri de kişilikleridir. Bu nedenle tüketicilerin kişilik özelliklerinin tespit edilerek, hedonik tüketim davranışları ile ilişkisinin ortaya konulması bu araştırmanın amacını oluşturmaktadır. Bu amaç doğrultusunda, araştırma katılımcılarının kişilik özellikleri beş faktör kişilik envanteri ile tespit edilmiş, katılımcıların beş faktör kişilik tipleri belirlenmiştir. Daha sonra katılımcıların kişilik tipleri ile hedonik tüketim güdüleri arasında ilişki olup olmadığ ve varsa ilişkinin yönü analiz edilmiştir.

\subsection{Araştırmanın Hipotezleri ve Modeli}

Hipotezler:

H1:Kişilik özellikleri ile macera amaçlı alışveriş arasında pozitif yönlü anlamlı bir etki vardır.

H2:Kişilik özellikleri ile sosyal amaçlı alışveriş arasında pozitif yönlü anlamlı bir etki vardır.

H3:Kişilik özellikleri ile değer amaçlı alışveriş arasında pozitif yönlü anlamlı bir etki vardır.

H4:Kişilik özellikleri ile fikir amaçlı alışveriş arasında pozitif yönlü anlamlı bir etki vardır.

H5:Kişilik özellikleri ile başkalarını mutlu etme amaçlı alışveriş arasında pozitif yönlü anlamlı bir etki vardır.

H6: Kişilik özellikleri ile rahatlama amaçlı alısveriş arasında pozitif yönlü anlamlı bir etki vardır. 


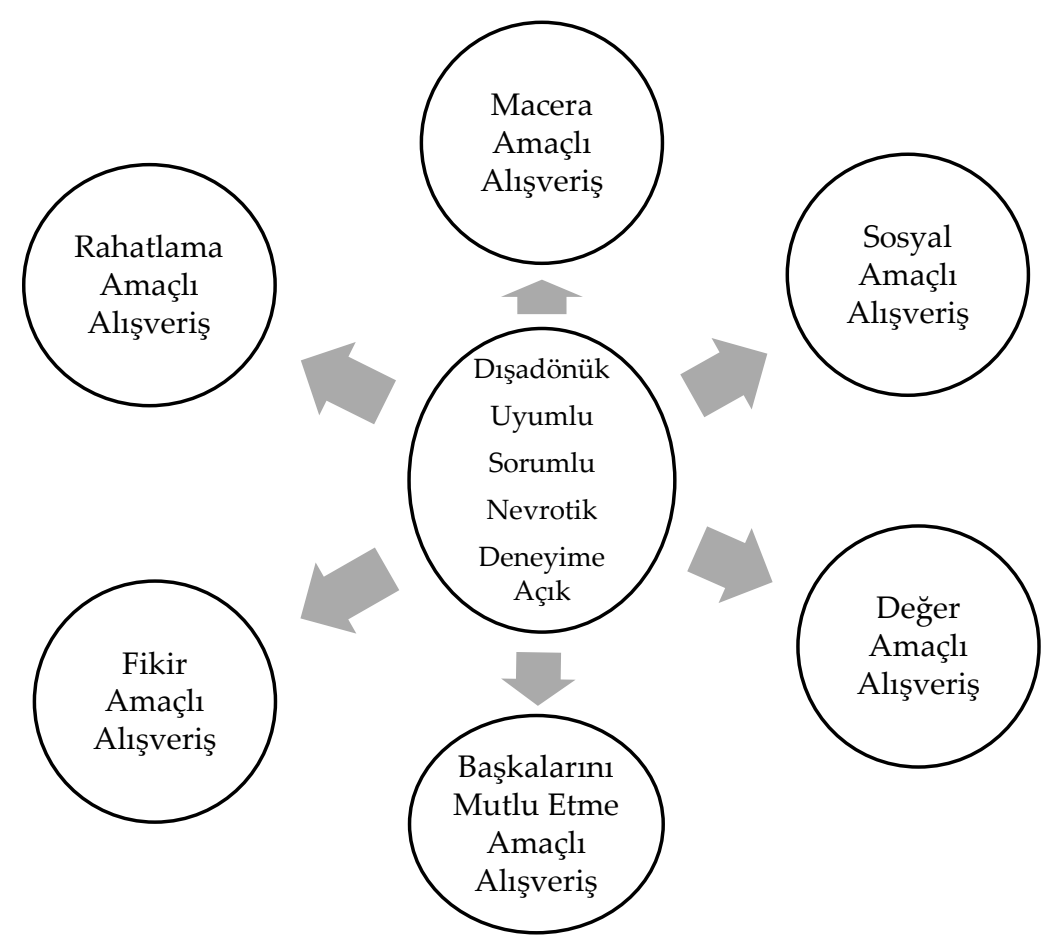

Şekil 1. Araştıma modeli

Araştırma hipotezleri doğrultusunda oluşturulan model Şekil 1'de gösterilmektedir.

\subsection{Araştırmanın Örneklemi}

Hazırlanan bu araştırma kapsamında örnekleme ulaşılırken amaca uygun ve kolay ulaşılabilir örnekleme yöntemi tercih edilmiş, araştırma örneklemine dâhil edilecek tüketicilere ilişkin ölçütler, amaçsal örnekleme yöntemi kapsamında seçilmiştir. Kozak (2015), Nicel araştırmalarda 300-400 adet arasında değişen soru formu sayısının sağlıklı bir veri analizi için uygun olduğunu belirtmektedir. Bu kapsamda 2019 yılı Mayıs-Eylül ayları arasında hafta sonları Ankara ilinin Çankaya İlçesinde bulunan iki alışveriş merkezinde araştırmaya gönüllü katılan, gelire sahip ve satın alma gücü olduğunu beyan eden 18 yaş üstü 370 kişiye anket uygulanmıştır. Literatürde ifade edildiği gibi tüketicilerin postmodern döneme geçiş ile birlikte alışverişlerinde faydacı güdülerden ziyade hedonik güdülerin ağır bastığı ve tüketimi artık zevk almak için yaptıkları ifade edilmektedir. Bu varsayımdan hareketle, çalışmada özellikle bir ürün grubu belirtilmemiş, genel tüketim davranışlarının incelenebilmesi açısından son alışveriş deneyimleri konu edilmiştir. Araştırmada katılımcıların anket sorularına içtenlikle cevap verdiği varsayılmaktadır.

\subsection{Araştırmada Kullanılan Ölçekler}

Araştırmada iki adet ölçek kullanılmıştır. Ölçeklerden ilki Fettahlıŏlu, Yıldız ve Birin (2014)'in kullanmış oldukları hedonik alışveriş ölçeğidir. Ölçeğin ilk hali 20 ifadeden oluşmaktadır. Ölçekte yer alan ifadeler 5'li Likert ölçeği şeklinde "1.kesinlikle katılmıyorum-5. kesinlikle katılıyorum" ifadeleriyle uygulanmıştır. Faktör analizi sonrası hedonik alışveriş ölçeğinde yer alan ifadelerin faktör yükleri incelenmiş ve 0,50 'nin altında kalan 6. ve 9. ifadeler ölçekten çıkartılmıştır. Tablo 2'de gösterilen Hedonik alışveriş ölçeği 18 ifade olarak analizlere tabi tutulmuştur.

Ankette yer alan bir diğer ölçek ise John, Donahue ve Kentle (1991) ile John, Naumann ve Soto (2008)'nun çalışmalarında kullandıkları, Türkçe'ye uyarlama, geçerlik ve güvenirlik çalışmaları Karaman, Doğan ve Çoban (2010) tarafından gerçekleştirilen 44 ifadeli, 5 alt kişilik tipinden oluşan beş faktör kişilik envanteri (BFI)'dir. Beş faktör kişilik envanteri, beş temel boyut açısından (dişadönük, deneyime açık, uyumlu, sorumlu ve nevrotik) kişilik tiplerini belirlemek ve açıklamak için kullanılan bir yapıdır (McCrae ve John, 1992: 175). Beş Faktör Kişilik envanteri, kültürel ve bireysel farklılıkları anlamak için temel ve güvenilir evrensel bir ölçektir (Bandura, 1999; McCrae ve Costa, 1999; Schmitt, Allik, McRae ve Benet-Martinez, 2007; Steenkamp ve Maydeu-Olivares, 2015). 
A. Solunoğlu - A. Nalçacı İkiz 12/3 (2020) 2344-2361

Tablo 1. Beş Faktör Kişilik Envanterinin Boyutlarına Ait Maddeler

Dişadönüklük

Uyumluluk

Sorumluluk

Nevrotiklik

Deneyime Açıklık

Beş faktör kişilik envanteri toplamda 44 madde ve beş adet kişilik alt boyutundan oluşmaktadır. Envanterdeki her alt boyutu ifade eden maddeler Tablo 1'de yer almaktadır. R simgesi ters döndürülen maddeleri işaret etmektedir.

\subsection{Araştırmanın Veri Toplama Yöntemi ve Verilerin Analizi}

Veri toplama işlemine başlamadan önce, ölçeklerin anlaşılabilirliğini ölçmek adına yapılan pilot çalışma sonucunda ölçek maddelerinin anlaşılırlığında bir sorun olmadığı tespit edilmiştir. Daha sonra hazırlanan anket formları nicel veri toplama yöntemlerinden yüz yüze görüşme tekniğiyle uygulanmıştır. Anket yardımıyla toplanan veriler sosyal bilimler için geliştirilen bir istatistik programı yardımıyla analiz edilmiştir. Verilerin analizi için tanımlayıcı ve tahminleyici istatistiki yöntemlerden yararlanılmıştır.

\section{ARAŞTIRMANIN BULGULARI}

Katılımcıların demografik özelliklerini tanımlayabilmek amacıyla frekans ve yüzde dağılımlarına bakılmıştır. İlgili istatistik programına veriler kodlanarak girilirken 16 anket formunun eksik ve hatalı doldurulduğu tespit edilerek analizlerden çıkartılmış, geriye kalan 354 anket formunda yer alan veriler kodlanmıştır. Örneklemden elde edilen veriler, analiz edilmeden önce "Kayıp Değer", ve "Uç Değer" analizleri yapılarak veriler yeniden düzenlenmiştir. Bu amaçla verilerin boxplot değerleri incelenmiş rastgele ve özensiz işaretlemelerden kaynaklanabilecek olan uç değerler tespit edilmiştir. İlgili değerlerin yer aldığı seriye ilişkin veriler analizlerden çıkartılarak, ilgili serinin ortalaması alınıp kayıp değerler yeniden atanmıştır. 354 anket formundan elde edilen veri seti böylece son şeklini almıştır. Verilerin normal dağılıma sahip olup olmadığını analiz etmek için "Çarpıklık ve Basıklık" değerleri incelenmiştir. Tabachnik, Fidell ve Ullman (2007) verilerin çarpıklık ve basıklık değerlerinin -1,5 ile 1,5 arasında olması durumunda normal dağılmış kabul edileceğini ifade etmektedir. Ölçeğe ilişkin değerlerin -1,5 ile 1,5 aralığında olduğu ve ilgili değişkenlere ait verilerin çoklu normal dağılım gösterdiği tespit edilmiştir.

Ölçekte yer alan her bir alt boyuta ilişkin güvenirlik katsayıları incelenmiş Tablo 2'de gösterilmiştir. Tablo 2'e göre ilgili değerlerin 0,746 ila 0,906 arasında değerlere sahip olduğu görülmüştür. Ayrıca her bir değişkene ilişkin ortalama açıklanan varyans (AVE) değerlerinin 0,50 üzerinde olduğu (minimum 0,508), bileşik güvenilirlik değerlerinin (CR) ise 0,70 üzerinde olduğu (minimum 0,753) tespit edilmiştir. 
A. Solunoğlu - A. Nalçacı İkiz 12/3 (2020) 2344-2361

Tablo 2. Verilerin Dağılımı ve Güvenilirliğine İlişkin Bulgular

\begin{tabular}{|c|c|c|c|c|c|c|c|c|}
\hline \multirow[t]{2}{*}{ Faktörler / Maddeler } & Standart & \multicolumn{2}{|c|}{ Çarpıklık } & \multicolumn{2}{|l|}{ Basıklık } & \multirow{2}{*}{ CR } & \multirow[b]{2}{*}{ AVE } & \multirow[t]{2}{*}{$\alpha$} \\
\hline & Yükler & & & & & & & \\
\hline Faktör MAV: Maceracı Alışveriş & & Statistic & $\begin{array}{l}\text { Std. } \\
\text { Error }\end{array}$ & Statistic & $\begin{array}{l}\text { Std. } \\
\text { Error }\end{array}$ & 0,906 & 0,708 & 906 \\
\hline $\begin{array}{l}\text { 1- Benim için alışveriş coşku verici } \\
\text { bir olaydır. }\end{array}$ & 853 &,- 109 & 130 & $-1,072$ & 259 & & & \\
\hline $\begin{array}{l}\text { 2- Alışveriş yapmak bana her zaman } \\
\text { için ilgi çekici gelmiştir }\end{array}$ & 874 &,- 139 & 130 & $-1,027$ & 259 & & & \\
\hline $\begin{array}{l}\text { 3- Alışverişe çıtı̆̆ım zaman } \\
\text { kendimi başka bir dünyada ve çok } \\
\text { güçlü hissederim. }\end{array}$ & 808 & 221 & 130 &,- 957 & 259 & & & \\
\hline $\begin{array}{l}\text { 4- Alışverişte zaman geçirmek haz } \\
\text { vericidir }\end{array}$ & 829 &,- 086 & 130 & $-1,072$ & ,259 & & & \\
\hline Faktör SAAV:Sosyal Amaçlı Alışveriş & & & & & & 0,755 & ,508 & ,766 \\
\hline $\begin{array}{l}\text { 5- Bana göre tanıdıklarla alışverişe } \\
\text { çıkmak yeni } \quad \text { paylaşımlar } \\
\text { yaşamaktır. }\end{array}$ & ,775 & -162 & 130 &,- 845 & 259 & & & \\
\hline
\end{tabular}

6- Bana göre tanıdıklarla alışverişe ,500

çıkmak onlarla eğlenceli vakit

geçirmek için bir fırsattır

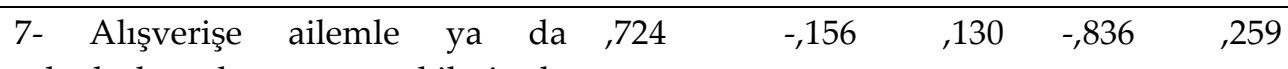

arkadaşlarımla etkileşimde

bulunmak, sosyalleşmek için giderim.

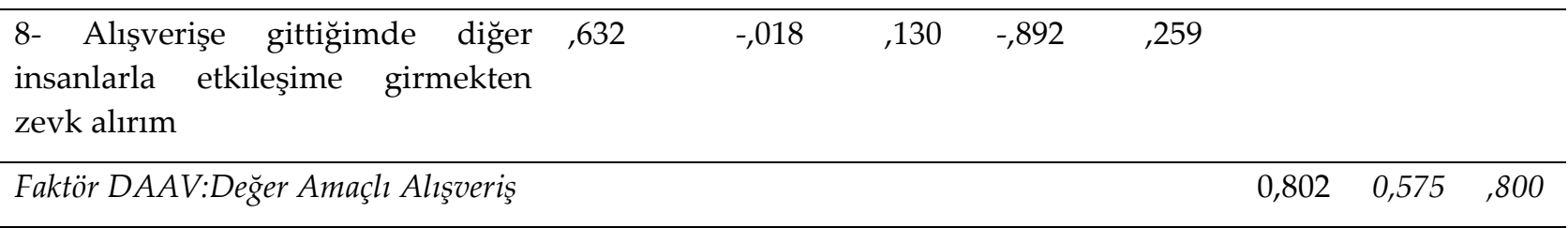

9-Alışverişe indirim zamanlarının ,349

avantajlarından faydalanmak için

giderim

\begin{tabular}{llllll}
\hline $\begin{array}{l}\text { 10-Alışverişe çıktığımda indirimli } \\
\text { ürünleri arayıp bulmak hoşuma } \\
\text { gider }\end{array}$ & &,- 436 &, 130 &,- 724 &, 259 \\
\hline $\begin{array}{l}\text { 11- Alışverişe çoğunlukla indirim } \\
\text { zamanlarında çıkarım. }\end{array}$ & 782 &,- 020 &, 130 &,- 832 &, 259 \\
\hline $\begin{array}{l}\text { 12- Alışverişe çıktığımda } \\
\text { indirimdeki ürünleri başkalarından } \\
\text { önce yakalayıp bulmaktan çok zevk } \\
\text { alırım. }\end{array}$ & & & & & \\
\hline
\end{tabular}

Faktör FAAV:Fikir Amaçlı Alışveriş

$0,761 \quad 0,520,748$

13- Alışverişe piyasadaki en son ,685 $\quad$ 259

ürünleri görmek için çıkarım. 
A. Solunoğlu - A. Nalçacı İkiz 12/3 (2020) 2344-2361

14- Alışverişe son modayı takip , 839 259 etmek için çıkarım.

\begin{tabular}{|c|c|c|c|c|c|c|c|c|}
\hline $\begin{array}{l}\text { 15- Markalı ürünleri almak beni } \\
\text { mutlu eder }\end{array}$ & 621 & 132 & 130 & $-1,122$ & 259 & & & \\
\hline $\begin{array}{l}\text { Faktör BMEAAV:Başkalarımı Mutlu } \\
\text { Etmek Amaçlı Alışveriş }\end{array}$ & & & & & & 0,753 & 0,505 & ,746 \\
\hline $\begin{array}{l}\text { 16- Alışverişe başkalarına bir şeyler } \\
\text { satın almak için giderim. Çünkü } \\
\text { onlar mutlu olduklarında ben de } \\
\text { olurum }\end{array}$ & 696 & -052 & 130 &,- 767 & 259 & & & \\
\hline $\begin{array}{l}\text { 17- Ailem ve arkadaşlarım için } \\
\text { alışveriş yapmaktan zevk alırım }\end{array}$ & 778 &,- 519 & 130 &,- 475 & 259 & & & \\
\hline $\begin{array}{l}\text { 18- Hediye alırken mükemmeli } \\
\text { bulmak için zaman ve çaba } \\
\text { harcamaktan çok hoşlanırım. }\end{array}$ & 653 &,- 325 & 130 &,- 912 & 259 & & & \\
\hline $\begin{array}{l}\text { Faktör RAAV:Rahatlama Amaçlı } \\
\text { Alışveriş }\end{array}$ & & & & & & 0,837 & 0,720 & ,835 \\
\hline $\begin{array}{l}\text { 19-. Belirli bir ihtiyacım olmasa da } \\
\text { mağazaları gezip ürünleri } \\
\text { incelemek bana haz verir }\end{array}$ & 883 &,- 040 & 130 & $-1,088$ & 259 & & & \\
\hline $\begin{array}{l}\text { 20-Alışveriş yapmasamda } \\
\text { mağazaları gezmek bana haz verir }\end{array}$ & 812 & ,064 & 130 & $-1,205$ & 259 & & & \\
\hline
\end{tabular}

Araştırmada kullanılan Beş Faktör Kişilik Envanteri (BFI)'nde yer alan 44 ifadeye ilişkin güvenirlik ölçeği ise Tablo 3'te gösterilmiş ve ,712 olarak tespit edilmiştir. Sosyal bilimler alanında "0,80 -100" arasında çıkan Cronbach's Alfa değerlerinin oldukça yüksek derecede güvenilir ve "0,60 - 0,80" arasında çıkan Cronbach's Alfa değerlerinin oldukça güvenilir olarak kabul edildiğinden (Kalaycı, 2009: 405), bu araştırmada kullanılan ölçeklerin oldukça güvenilir olduğu değerlendirmesi yapılabilir.

Tablo 3. Beş Faktör Kişilik Envanteri Genel Güvenirlik Katsayısı

\begin{tabular}{lll}
\hline & Madde Sayıs & Cronbach's Alfa \\
\hline Toplam & 44 &, 712 \\
\hline
\end{tabular}

Beş faktör kişilik envanterinde (BFI) genel güvenirlik katsayısı ,712 olarak tespit edilmiştir. Tüketicilerinin demografik özelliklerine ilişkin bulgular Tablo 4 'te yer almaktadır.

Tablo 4. Demografik Özelliklere İlişkin Bulgular

\begin{tabular}{lllllc}
\hline Yaş & Sayı & $\mathbf{\%}$ & Meslek & Sayı & $\mathbf{\%}$ \\
\hline $18-24$ yaş & 71 & 20,1 & Kamu Personeli & 125 & 35,3 \\
\hline $25-34$ yaş & 103 & 29,1 & Özel Sektör & 106 & 29,9 \\
\hline $35-44$ yaş & 74 & 20,9 & Serbest Meslek & 32 & 9,0 \\
\hline $45-54$ yaş & 80 & 22,6 & Emekli & 22 & 6,2 \\
\hline 55 ve üzeri & 26 & 7,3 & Çalışmıyor & 42 & 11,9 \\
\hline & & & Diğer & 27 & 7,6 \\
\hline
\end{tabular}


A. Solunoğlu - A. Nalçacı İkiz 12/3 (2020) 2344-2361

\begin{tabular}{|c|c|c|c|c|c|}
\hline Gelir & Sayı & $\%$ & Ĕgitim & Sayı & $\%$ \\
\hline 2020 TL ve daha az & 40 & 11,3 & İlköğretim & 54 & 15,3 \\
\hline $2021-3500 \mathrm{TL}$ & 115 & 32,5 & Lise & 117 & 33,1 \\
\hline $3501-5000 \mathrm{TL}$ & 94 & 26,6 & Üniversite & 145 & 41,0 \\
\hline $5001-6500 \mathrm{TL}$ & 57 & 16,1 & LisansÜstü & 38 & 10,7 \\
\hline $6500+\mathrm{TL}$ & 48 & 13,1 & & & \\
\hline Cinsiyet & Say1 & $\%$ & Çocuk Sayısı & Sayı & $\%$ \\
\hline Kadın & 140 & 39,3 & Çocuksuz & 126 & 35,6 \\
\hline Erkek & 214 & 60,5 & 1 Çocuk & 42 & 11,9 \\
\hline Medeni Durum & Sayı & $\%$ & 2 Çocuk & 109 & 30,8 \\
\hline Bekâr & 123 & 34,7 & 3+ Çocuk & 77 & 21,7 \\
\hline Evli & 231 & 65,3 & & & \\
\hline Toplam & 354 & 100 & & 354 & 100 \\
\hline
\end{tabular}

Çalışmaya katılan tüketicilerin demografik özellikleri incelendiğinde \%65,3'ünün (231 kişi) evli, \%34,7'sinin (123) bekâr olduğu, eğitim durumları açısından \%41'inin (145 kişi) üniversite, \%33,1'inin (117 kişi) lise mezunu olduğu, meslek grupları açısından değerlendirildiğinde \%35,3'ün (125 kişi) kamu personeli, \%29,9'unun ise (106 kişi) özel sektör çalışanı olduğu, cinsiyet değişkeni açısından \%60,5'inin (214 kişi) erkek, \%39,3'ünün (140 kişi) kadın olduğu tespit edilmiştir. Ayrıca çocuk sayısı açısından \%35,6'sının (126 kişi) çocuk sahibi olmadığı, \%30,8'inin (109 kişi) ise iki çocuğu olduğu, gelir durumu açısından \%32,5'inin (115 kişi) 2021 TL-3500 TL aralığında gelire sahip olduğu, \%26,6'sının (94 kişi) ise 3501 TL-5000 TL arası gelir sahip olduğu belirlenmiştir.

Tablo 5. Katılımcıların Kişilik Özelliklerine Göre Dağılımları

\begin{tabular}{lll}
\hline Kişilik Özellikleri & $\mathbf{N}$ & $\mathbf{\%}$ \\
\hline Dişa Dönük & 76 & 21,5 \\
\hline Uyumlu & 79 & 22,3 \\
\hline Sorumlu & 109 & 30,8 \\
\hline Nevrotik & 34 & 9,6 \\
\hline Deneyime Açık & 56 & 15,8 \\
\hline Toplam & $\mathbf{3 5 4}$ & $\mathbf{1 0 0}$ \\
\hline
\end{tabular}

Katılımcıların kişilik özellikleri beş faktör kişilik envanteri ile ölçülmüş ve katılımcıların verdikleri yanıtlara göre; her bir kişilik özelliği için, alt boyutlarının ortalamaları alındıktan sonra en yüksek ortalamaya sahip her katılımcının o kişilik özelliğine sahip olduğu belirlenmiştir. Tablo 5'e göre toplamda 354 kişi olan katılımcılardan \%21,5'i (76 kişi) dışa dönük, \%22,3’ü (79 kişi) uyumlu, \%30,8'i (109 kişi) sorumlu, \%9,6'sı (34 kişi) nevrotik ve \%15,8'i ise (56 kişi) deneyime açık kişilik özelliğine sahip olduğu görülmektedir.

Korelasyon katsayısı, iki veya daha fazla sayıdaki değişken arasındaki ilişkinin miktarını ve yönünü belirleyebilmek için uygulanmaktadır. Büyüköztürk (2002: 31-32)'e göre korelasyon katsayısı -1.00 ila 1.00 arasında bir değer alabilmektedir. Bu değer -1 ise mükemmel negatif bir ilişkiyi, 0 ilişki olmadığını, 1 ise mükemmel pozitif bir ilişkiyi ifade etmektedir. Ayrıca korelasyon katsayısının 0,70-1,00 arasında olması, yüksek; 0,30-0,69 aralığında olması, orta; 0,00-0,29 arasında olması ise düşük düzeyde ilişki olarak ifade edilmektedir. Buna göre Tablo 6' da değişkenlere ait korelasyon katsayıları görülmektedir. 
A. Solunoğlu - A. Nalçacı İkiz 12/3 (2020) 2344-2361

Tablo 6. Değişkenlere ait Korelasyon Katsayıları Matrisi

\begin{tabular}{|c|c|c|c|c|c|c|c|}
\hline & & $\begin{array}{l}\text { Macera } \\
\text { Amaçlı }\end{array}$ & $\begin{array}{l}\text { Sosyal } \\
\text { Amaçlı }\end{array}$ & $\begin{array}{l}\text { Değer } \\
\text { Amaçlı }\end{array}$ & $\begin{array}{l}\text { Fikir } \\
\text { Amaçlı }\end{array}$ & $\begin{array}{l}\text { BME } \\
\text { Amaçlı }\end{array}$ & Rahatlama Amaçlı \\
\hline \multirow[t]{2}{*}{ Dişadönük } & $\begin{array}{l}\text { Pearson } \\
\text { Correlation }\end{array}$ &, $167^{* *}$ & ,090 & , 087 & ,013 &, $297^{* *}$ & ,047 \\
\hline & Sig. (2-tailed) & ,002 & ,089 & 102 & ,808 & ,000 & ,373 \\
\hline \multirow[t]{2}{*}{ Uyumlu } & $\begin{array}{l}\text { Pearson } \\
\text { Correlation }\end{array}$ & ,063 & ,090 & ,029 &,$- 166^{* *}$ & $346^{* *}$ & ,006 \\
\hline & Sig. (2-tailed) & ,239 & ,092 &, 588 & ,002 & ,000 & ,917 \\
\hline \multirow[t]{2}{*}{ Sorumlu } & $\begin{array}{l}\text { Pearson } \\
\text { Correlation }\end{array}$ & ,010 & ,031 &,- 029 &,$- 173^{* *}$ &, $323^{* *}$ &,- 026 \\
\hline & Sig. (2-tailed) & ,851 &, 557 & ,592 & ,001 & ,000 & 626 \\
\hline \multirow[t]{2}{*}{ Nevrotik } & $\begin{array}{l}\text { Pearson } \\
\text { Correlation }\end{array}$ &,- 002 &,- 049 &,- 013 & ,095 &,$- 186^{* *}$ & ,033 \\
\hline & Sig. (2-tailed) & ,963 & ,359 & 807 & 076 & ,000 &, 540 \\
\hline \multirow[t]{2}{*}{ DeneyimeAçık } & $\begin{array}{l}\text { Pearson } \\
\text { Correlation }\end{array}$ & $251^{* *}$ & $131^{*}$ & $171^{* *}$ & ,082 &, $329 * *$ & $128^{*}$ \\
\hline & Sig. (2-tailed) & ,000 & ,014 & ,001 & ,122 & ,000 & ,016 \\
\hline
\end{tabular}

Korelasyon matrisi incelendiğinde değişkenler arası en yüksek korelasyonun uyumlu kişilik tipi ile başkalarını mutlu etme amaçlı alışveriş boyutu arasında olduğu, ilgili korelasyonun anlamlı, pozitif, çift yönlü ve orta düzeyde $(\mathrm{r}=, 346, \mathrm{p}<0,01)$ olduğu görülmektedir. İkinci yüksek korelasyona sahip değişkenlerin ise deneyime açık kişilik tipi ile başkalarını mutlu etme amaçlı alışveriş boyutu arasında görülmektedir. Matrise göre bu iki değişken arasında anlamlı, pozitif, çift yönlü ve orta düzeyde $(r=, 329, p<0,01)$ bir korelasyon bulunmaktadır. Matris incelendiğinde ayrıca sorumlu kişilik tipi ile başkalarını mutlu etme amaçlı alışveriş boyutu arasında anlamlı, pozitif çift yönlü ve orta düzeyde $(r=323, \mathrm{p}<0,01)$ olduğu görülmektedir.

İlgili değişkenler içerisinde başkalarını mutlu etme amaçlı alışveriş boyutu ile tüm kişilik tipleri arasında istatistiksel açıdan anlamlı ilişkiler tespit edilse de nevrotik kişilik tipine sahip kişiler ile başkalarını mutlu etme amaçlı alışveriş boyutu arasında negatif, çift yönlü ve düşük bir korelasyon olduğu görülmektedir(r=,186, $\mathrm{p}<0,01)$.

Dışa dönük kişilik tipi ile macera amaçlı alışveriş boyutu arasında anlamlı, pozitif, çift yönlü ve düşük düzeyde $(\mathrm{r}=, 167, \mathrm{p}<0,01)$ bir ilişki olduğu görülmektedir. Bunun yanı sıra uyumlu kişilik tipi ile fikir amaçlı alışveriş boyutu arasında anlamlı, çift yönlü fakat negatif ve düşük düzeyde bir korelasyon olduğu tespit edilmiştir ( $\mathrm{r}=-, 166, \mathrm{p}<0,01)$. Benzer şekilde sorumlu kişilik tipi ile fikir amaçlı alışveriş boyutu arasında negatif ve düşük düzeyde, çift yönlü bir ilişki görülmektedir $(r=-, 173, p<0,01)$.

Ayrıca tablo incelendiğinde deneyime açık kişilik tipinin hedonik tüketim alt boyutlarından, macera amaçlı ve değer amaçlı alışveriş boyutları ile çift yönlü, pozitif, anlamlı ve düşük düzeyde bir ilişkisi olduğu (sırasıyla $\mathrm{r}=, 251, \mathrm{r}=171$ ve $\mathrm{p}<0,01$ ), sosyal amaçlı alışveriş boyutu ve rahatlama amaçlı alışveriş boyutları ile tek yönlü, pozitif, anlamlı ve düşük düzeyde bir ilişkisi olduğu görülmektedir (sırasıyla $r=, 131, r=, 128$ ve $p<0,05$ ). Deneyime açık kişilik tipinin fikir amaçlı alışveriş boyutu $(r=, 082, p>0,05)$ ile anlamlı bir ilişkisi olmadığı görülmektedir.

\subsection{Kişilik Tiplerinin Hedonik Tüketim Tercihlerini Etkilemesine Yönelik Bulgular}

Katılımcıların sahip oldukları kişilik tiplerini hedonik tüketim tercihlerini belirlemeye yönelik beş faktör kişilik envanteri alt boyutları ile her bir hedonik tüketim tercihi alt boyutuyla arasında çoklu regresyon analizi uygulanmıştır. Analizler sonucu elde edilen bulgular tablolar yardımıyla aktarılmıştır. 
A. Solunoğlu - A. Nalçacı İkiz 12/3 (2020) 2344-2361

Tablo 7. Beş Faktör Kişilik Özelliklerinin Hedonik Tüketimin Alt Boyutları Üzerindeki Etkisi

\begin{tabular}{|c|c|c|c|c|c|}
\hline \multirow[t]{2}{*}{ Faktörler } & \multicolumn{3}{|c|}{$\begin{array}{l}\text { Çoklu Doğrusal } \\
\text { Bağlantı }\end{array}$} & \multicolumn{2}{|l|}{ Macera Amaçlı Alışveriş } \\
\hline & $\begin{array}{l}\text { Standardize } \\
\text { Edilmemiş } \beta\end{array}$ & Tolerans & VIF & $\mathrm{t}$ & $\mathrm{p}$ \\
\hline Dişadönük & , 179 & 680 & 1,471 & 1,714 & ,087 \\
\hline Uyumlu & 137 & ,595 & 1,680 & 972 & ,332 \\
\hline Sorumlu &,- 318 & ,537 & 1,862 & $-2,641$ & ,009* \\
\hline Nevrotik & 093 & 693 & 1,442 & ,787 & 432 \\
\hline Deneyime Açık & 652 & 669 & 1,494 & 4,422 & , $000^{*}$ \\
\hline (Sabit) & 631 & & & 814 & ,416 \\
\hline \multirow{2}{*}{$\mathrm{R}=, 299$} & Adj. $R^{2}=, 079$ & \multicolumn{2}{|l|}{$\mathrm{F}=6,814$} & $\mathrm{D} / \mathrm{W}=1,686$ & $\mathrm{p}=, 000$ \\
\hline & & \multicolumn{4}{|c|}{ Sosyal Amaçlı Alışveriş } \\
\hline Dişadönük & 059 & 680 & 1,471 & 631 & ,529 \\
\hline Uyumlu & , 163 &, 595 & 1,680 & 1,284 & 200 \\
\hline Sorumlu &,- 152 & ,537 & 1,862 & $-1,403$ & 162 \\
\hline Nevrotik &,- 010 & 693 & 1,442 &,- 907 & ,923 \\
\hline Deneyime Açık & ,263 & 669 & 1,494 & 1,988 & ,048 \\
\hline (Sabit) & 1,989 & & & 2,856 & ,005 \\
\hline \multirow{2}{*}{$\mathrm{R}=, 160$} & Adj. $R^{2}=, 012$ & \multicolumn{2}{|l|}{$\mathrm{F}=1,825$} & $\mathrm{D} / \mathrm{W}=1,732$ & $\mathrm{p}=, 107$ \\
\hline & & \multicolumn{4}{|c|}{ Değer Amaçlı Alışveriş } \\
\hline Dişadönük & 064 & 680 & 1,471 & 661 & ,509 \\
\hline Uyumlu & , 078 & ,595 & 1,680 & ,588 & ,557 \\
\hline Sorumlu &,- 281 & ,537 & 1,862 & $-2,495$ & $013^{*}$ \\
\hline Nevrotik &,- 012 & 693 & 1,442 &,- 106 & ,916 \\
\hline Deneyime Açık & 474 & 669 & 1,494 & 3,439 &, $001^{*}$ \\
\hline (Sabit) & 2,104 & & & 2,904 & ,004 \\
\hline \multirow[t]{2}{*}{$\mathrm{R}=, 218$} & Adj. $R^{2}=, 034$ & \multicolumn{2}{|l|}{$F=3,469$} & $\mathrm{D} / \mathrm{W}=1,820$ & $\mathrm{p}=, 004$ \\
\hline & & \multicolumn{4}{|c|}{ Fikir Amaçlı Alışveriş } \\
\hline Dişadönük & ,079 & 680 & 1,471 & 836 & ,000* \\
\hline Uyumlu &,- 239 & ,595 & 1,680 & $-1,871$ & ,404 \\
\hline Sorumlu &,- 347 &, 537 & 1,862 & $-3,181$ & ,062 \\
\hline Nevrotik & $\begin{array}{ll}-005 \\
\end{array}$ & 693 & 1,442 &,- 044 & ,002* \\
\hline Deneyime Açı & 434 & 669 & 1,494 & 3,246 & 965 \\
\hline (Sabit) & \multicolumn{3}{|l|}{3,076} & 4,383 & ,001 \\
\hline $\mathrm{R}=, 277$ & Adj. $R^{2}=, 063$ & \multicolumn{2}{|l|}{$\mathrm{F}=5,772$} & $\mathrm{D} / \mathrm{W}=2,002$ & $\mathrm{p}=, 000$ \\
\hline
\end{tabular}


A. Solunoğlu - A. Nalçacı İkiz 12/3 (2020) 2344-2361

\begin{tabular}{|c|c|c|c|c|c|}
\hline & & \multicolumn{4}{|c|}{ BME Amaçlı Alışveriş } \\
\hline Dişadönük & ,170 & 680 & 1,471 & 2,001 &, $046^{*}$ \\
\hline Uyumlu & ,415 & ,595 & 1,680 & 3,607 &, $000^{*}$ \\
\hline Sorumlu & ,121 & ,537 & 1,862 & 1,231 & ,219 \\
\hline Nevrotik & ,072 & ,693 & 1,442 & ,746 & 456 \\
\hline Deneyime Açık & ,339 & ,669 & 1,494 & 2,817 &, $005^{*}$ \\
\hline (Sabit) & \multicolumn{3}{|l|}{,- 510} &,- 807 & 420 \\
\hline \multirow[t]{2}{*}{$\mathrm{R}=, 431$} & Adj. $R^{2}=, 174$ & \multicolumn{2}{|l|}{$\mathrm{F}=15,895$} & $\mathrm{D} / \mathrm{W}=1,847$ & $p=, 000$ \\
\hline & & & & \multicolumn{2}{|c|}{ Rahatlama Amaçlı Alışveriş } \\
\hline Dişadönük & ,029 & 680 & 1,471 & ,249 & ,803 \\
\hline Uyumlu & ,065 &, 595 & 1,680 & 409 & 683 \\
\hline Sorumlu &,- 215 & ,537 & 1,862 & $-1,573$ & ,117 \\
\hline Nevrotik & ,091 & 693 & 1,442 & 679 & 498 \\
\hline Deneyime Açık & ,454 & 669 & 1,494 & 2,718 & ,007 \\
\hline (Sabit) & \multicolumn{3}{|l|}{1,609} & $1,, 833$ & ,068 \\
\hline $\mathrm{R}=, 167$ & Adj. $R^{2}=, 014$ & \multicolumn{2}{|l|}{$\mathrm{F}=1,988$} & $\mathrm{D} / \mathrm{W}=1,887$ & $\mathrm{p}=, 080$ \\
\hline
\end{tabular}

$\mathrm{D} / \mathrm{W}=$ Durbin-Watson

Regresyon modelinde birden fazla bağımsız değişkenin bulunması durumunda (dışadönük, uyumlu, sorumlu, nevrotik, deneyime açı) ilgili değişkenler arasında çoklu doğrusal bağlantı problemi incelenmelidir $\mathrm{Bu}$ amaçla tolerans ve VIF değerleri dikkate alınmalıdır. Hair, Bush ve Ortnau (2003) tolerans değerinin 0,10 üzerinde olması gerektiğini ifade etmektedir. Allison (1999)'a göre ise VIF değerinin 2,5 altında olması gereklidir. Tablo 7 incelendiğinde bu değerlerin ilgili değerleri karşıladığı ve çoklu doğrusal bağlantı probleminin olmadığı görülmektedir. Ayrıca bağımsız değişkenler arasında incelenmesi gereken bir diğer değer Durbin-Watson değeridir. Değişkenler arasındaki otokorelasyonun varlığını ifade eden bu değerin 1,5 ila 2,5 arasında olması gereklidir (Kalaycı, 2006: 264) Tablolar incelendiğinde Durbin-Watson (D/W) değerlerinin 1,686 ile 2,002 arasında değerler aldığ1 görülmektedir.

$\mathrm{Bu}$ aşamadan sonra modelin genel olarak anlamlı olduğu, bağımsız değişkenlerin bağımlı değişken olan maceracı alışveriş boyutunu oldukça düşük düzeyde, pozitif yönde etkilediği görülmektedir (Adj. R2=,079, $\mathrm{p}<, 000)$. Tabloya göre sorumlu kişilik özelliği ile maceracı alışveriş boyutu arasında istatiksel olarak anlamlı fakat negatif yönlü $(\beta=-, 318, p<0,01)$ bir ilişki olduğu görülmektedir. Sorumlu kişilik özelliğindeki 1 birimlik artışın macera amaçlı alış veriş boyutu üzerinde -,318 birimlik azalışa sebep olabileceği tespit edilmiştir. Bunun yanı sıra deneyime açık kişilik özelliğinin macera amaçlı alışveriş boyutu üzerinde istatistiksel olarak anlamlı olduğu, orta düzeyde ve pozitif yönde etki ettiği görülmektedir $(\beta=, 652, p<0,01)$. Bu sonuca göre ise deneyime açık kişilik özelliğindeki 1 birimlik artış, macera amaçlı alışveriş üzerinde ,652 birimlik artışa sebep olabilmektedir. Buna göre H1 hipotezi kısmen kabul edilmiştir.

Bağımsız değişken olan kişilik özellikleri ile bağımlı değişken olan hedonik tüketimin alt boyutu olan sosyal amaçlı alışveriş arasında oluşturulan regresyon modelinin istatistiksel olarak anlamlı olmadığı tespit edilmiştir. Kişilik özelliklerindeki herhangi bir değişiklik sosyal amaçlı alışveriş boyutuna yönelik nötrdür (Adj. R2=,012, p>0,05). Yani H2 hipotezi ret edilmiştir. Tablo 6'da yer alan korelasyon matrisinde ise kişilik özelliklerinden sadece dışa dönük kişilik özelliğinin $(r=, 131, p<0,05)$ sosyal amaçlı alışveriş ile pozitif yönde, düşük düzeyde korelasyona sahip olduğu görülmüştür.

Katılımcıların kişilik tiplerinin değer amaçlı alışveriş boyutu üzerindeki regresyonu incelendiğinde bağımsız değişkenlerin bağımlı değişken olan değer amaçlı alışveriş boyutunu oldukça düşük düzeyde, pozitif yönde etkilediği görülmektedir (Adj. R2=,034, p<0,05). Tabloya göre maceracı alışveriş tüketim boyutunda olduğu 


\section{A. Solunoğlu - A. Nalçacı İkiz 12/3 (2020) 2344-2361}

gibi sorumlu kişilik özelliği ile değer amaçlı alışveriş boyutu arasında da istatiksel olarak anlamlı fakat negatif yönlü $(\beta=-, 281, p<0,05)$ bir ilişki olduğu görülmektedir. Sorumlu kişilik özelliğindeki 1 birimlik artışın değer amaçlı alış veriş üzerinde -,218 birimlik azalışa sebep olabileceği belirlenmiştir. Ayrıca benzer şekilde deneyime açı kişilik özelliğine sahip olanların değer amaçlı alışveriş boyutu üzerinde istatistiksel olarak anlamlı olduğu, orta düzeyde ve pozitif yönde etki ettiği görülmektedir $(\beta=, 474, p<0,01)$. Bu sonuca göre deneyime açık kişilik özelliğindeki 1 birimlik artış değer amaçlı alışveriş üzerinde ,474 birimlik artışa sebep olabilmektedir. Bu duruma göre $\mathrm{H} 3$ hipotezinin kısmen kabul edildiği sonucuna varılmaktadır.

Tablo 7'ye göre kişilik envanterinden yer alan alt boyutların, hedonik tüketim alt boyutlarından biri olan fikir amaçlı alışveriş üzerinde istatistiksel olarak anlamlı, pozitif yönlü fakat oldukça düşük bir etkisi olduğu görülmektedir (Adj. $R^{2}=, 063, p<0,01$ ). İlgili alt boyutlardan dışadönük kişilik özelliğinin fikir amaçlı alışveriş boyutunu pozitif yönde fakat düşük düzeyde etkilediği görülmektedir $(\beta=, 079, p<0,01)$. Elde edilen bulguya göre dışadönük kişilik özelliğinde meydana gelecek 1 birimlik artış fikir amaçlı alışverişi ,079 birim olumlu yönde etkileyebilecektir. Bunun yanı sıra nevrotik kişilik özelliğinin fikir amaçlı alışveriş üzerinde istatistiksel olarak anlamll, negatif yönlü fakat çok düşük düzeyde etkisi olduğu görülmektedir $(\beta=-, 005, p<0,01)$. Bu sonuçlar doğrultusunda H4 hipotezi kısmen kabul edilmiştir.

Kişilik envanterinde yer alan alt boyutlar arasında hedonik tüketim alt boyutlarına anlamlı ve pozitif yönde en yüksek etki, başkalarını mutlu etme amaçlı alışveriş alt boyutunda tespit edilmiştir (Adj. $R^{2}=, 174, p<0,01$ ). Yani H5 hipotezi desteklenmiştir. Buna göre başkalarını mutlu etmek amaçlı alışveriş alt boyutundaki değişkenliğin \%17,4'lük kısmı kişilik tipi alt boyutları tarafından açıklanmaktadır. Hangi kişilik tipinin etkili olduğu incelendiğinde ise en büyük etkinin uyumlu kişilik özelliğinde pozitif yönlü ve orta düzeyde olduğu $(\beta=, 415, \mathrm{p}<0,01)$, bunu deneyime açık $(\beta=, 339, \mathrm{p}<0,01)$ ve dışadönük kişilik özelliğinin $(\beta=, 170, \mathrm{p}<0,05)$ izlediği ifade edilebilir.

Regresyon modellerinden sonuncusu ise kişilik envanterinde yer alan boyutların rahatlama amaçlı alışverişle arasında oluşturulan modeli göstermektedir. Elde edilen bulgular sonucunda kişilik tipleri ve rahatlama amaçlı alışveriş alt boyutu arasında uygulanmak istenilen modelin istatistiksel olarak anlamlı olmadığ 1 görülmektedir (Adj. $\mathrm{R}^{2}=, 014, \mathrm{p}>0,05$ ). Bu sonuca göre $\mathrm{H} 6$ hipotezi ret edilmiştir.

\section{SONUÇ ve TARTIŞMA}

Hedonizm felsefik bir görüş olarak ortaya çıkmış olmasına rağmen tüketim alışkanlıklarının değişmeye başlamasıyla beraber çeşitli alanlarda araştırmalara konu olmuştur. Pazarlama alanında hedonik tüketim kavramı Hirschman ve Holbrook'un (1982) makalesinde ele alınarak açılanmış ve daha sonra birçok tüketim araştırmasında irdelenmiştir.

Günümüzde tüketicilerin sadece rasyonel beklentiler içerisinde alışveriş yapmadıkları, kişilik özelliklerine bağlı olarak oluşan duygularının da alışverişlerinde etkili olduğu düşünülmektedir. Bu nedenle tüketicilerin kişilik özelliklerinin tespit edilerek, hedonik tüketim alışkanlıklarının ortaya konulması önemli kabul edilmektedir. Zira işletmeler için tüketici profilinin doğru değerlendirilmesi, doğru stratejilerin seçilmesi ve pazara nüfuz edilmesi oldukça önemlidir. Tüketicilerin kişilik özelliklerinin tespit edilerek, hedonik tüketim davranışları ile ilişkisinin ortaya konulması amacını taşıyan bu çalışmadan elde edilen veriler doğrultusunda kişilik özellikleri ile hedonik tüketimin alt boyutları arasında çeşitli düzeylerde karşılıklı ilişki ve etkiler olduğu görülmektedir. Buna göre;

Dışadönük kişilik tipinin hedonik tüketimin alt boyutlarından macera amaçlı alışveriş ve başkalarını mutlu etme amaçlı alışveriş boyutları ile çift yönlü ilişkili olduğu, bunun yanı sıra dışadönük kişilik tipinin fikir amaçlı alışveriş ve başkalarını mutlu etme amaçlı alışveriş boyutları üstünde pozitif etkileri olduğu görülmektedir. Yani dişadönük kişilik özelliğine bağlı tüketim tercihlerinde yaşanan artış veya azalış benzer şekilde fikir amaçlı ve başkalarını mutlu etme amaçlı hedonik tüketim alt boyutlarında da artış veya azalışa sebep olabilecektir. Diğer taraftan bu iki hedonik tüketim boyutundan herhangi birinde oluşabilecek değişimler kişilik özelliğinden kaynaklanan satın alma tercihlerinde de aynı yönlü değişikliklere yol açacaktır.

Uyumlu kişilik tipinin fikir amaçlı alışveriş boyutu ile negatif yönlü, başkalarını mutlu etme amaçlı alışveriş boyutu ile ise pozitif yönlü ilişkisi olduğu görülmektedir. Elde edilen sonuçlar uyumlu kişilik tipinin başkalarını mutlu etme amaçlı alışverişi boyutunu orta düzeyde etkilediği görülmektedir. Bu anlamda hazırlanan bu araştırma literatür tarafından desteklenmektedir. Guido (2006), beş faktör kişilik tipleri ile 


\section{A. Solunoğlu - A. Nalçacı İkiz 12/3 (2020) 2344-2361}

hedonik ve faydacı alışverişin ilişkisini araştırdığı çalışmasında da Dışa dönüklük, Deneyime Açıklık ve Uyumluluk kişilik özelliklerinin Hedonik alışveriş ile ilişkili olduğunu göstermiştir. Yine, Flynn ve Goldsmith (2015) deneyime açık, dişadönük, uyumlu ve sorumlu kişilik özelliklerine sahip kişileri pazar maveni olarak tanımlamış ve bu tüketicilerin alışverişte daha yetkin olduğunu ifade etmişlerdir.

Sorumlu kişilik özelliğinin fikir amaçlı ve başkalarını mutlu etme amaçlı alışveriş boyutlarıyla ilişkili olduğu, sorumlu kişilik özelliğindeki olumlu artışın fikir amaçlı alışveriş boyutunda azalmaya neden olduğu, başkalarını mutlu etme amaçlı alışveriş boyutunda ise olumlu artış şeklinde etki gösterdiği tespit edilmiştir. Bunun yanı sıra sorumlu kişilik özelliğinde oluşabilecek değişimin macera amaçlı ve değer amaçlı alışveriş boyutlarını negatif yönde düşük düzeyde etkilediği görülmüştür. Bu sonuç, sorumlu kişilik özelliğine sahip bireylerin düzeni seven, planlı, tertipli, verimli ve kararlı özellikler göstermesi sebebiyle yaşamlarının planını değiştirecek herhangi bir alışveriş tarzını benimsemedikleri şeklinde ifade edilebilir.

Nevrotik kişilik özelliğine sahip bireylerin başkalarını mutlu etme amaçlı alışveriş boyutu ile negatif yönlü düşük düzeyde bir ilişkiye sahip olduğu görülmektedir. Bu durum, Kavut'un (2018) nevrotiklerde gözlemlenebilen tutumlardan birinin insanlarla temas kurma ve benzeri konularda ketlenmeleri olduğu görüşünü desteklemektedir. Ayrıca nevrotik kişilik özelliğinin fikir amaçlı alışveriş boyutu üzerinde anlamlı fakat negatif yönlü etkiye sahiptir. McRae ve John (1992) nevrotik kişilik özelliklerine sahip olanların dürtülerini daha az kontrol edebildiğini, stresle başa çıkamadığını ve çoğu insanı etkilemeyecek durumlara duygusal yanıtlar verdiğini ifade etmiştir. Goldsmith (2016) ise nevrotik tüketicilerin, daha az sosyal aktivite ile mutlu edilebileceğini belirtmiştir.

Elde edilen bulgular doğrultusunda, deneyime açık kişilik özelliğinin fikir amaçlı alışveriş boyutu dışındaki tüm hedonik alışveriş alt boyutları ile ilişkili olduğu görülmektedir. Macera amaçlı, değer amaçlı ve başkalarını mutlu etme alışveriş boyutlarıyla pozitif yönlü karşılıklı ilişkiye sahipken, sosyal amaçlı ve rahatlama amaçlı alışveriş boyutları ile yine pozitif yönlü fakat tek yönlü ilişkiye sahip olduğu tespit edilmiştir. Goldsmith de (2015), araştırmasında deneyime açık kişilik tipinin alışveriş üzerinde doğrudan bir etkisi olduğunu tespit etmiştir. Çoklu doğrusal regresyon tabloları incelendiğinde ise deneyime açık kişilik özelliğinin macera amaçlı, değer amaçlı, fikir amaçlı ve başkalarını mutlu etme amaçlı alışveriş boyutlarını pozitif yönlü orta düzeyde anlamlı şekilde etkilediği görülmektedir. Bu sonuç deneyime açık kişilik tipinin, bireylerin zihinsel ve deneyimsel yaşamlarındaki yeni olan her şeye gösterdiği toleransla (John ve Srivastava, 1999, s, 30) hareket ettiği sonucu ile tamamen bir uyum içerisindedir.

Beş faktör kişilik özelliklerinin tüketicilerin davranışları üzerinde etkisini inceleyen pek çok araştırma olsa da bu çalışma bireylerin kararlarını ve davranışlarını etkileyen kişilik özellikleri ile hedonik tüketimin boyutları arasındaki ilişkiyi ele alması bakımından önemli olduğu düşünülmektedir. Araştırmada gerek korelasyon gerekse de regresyon tabloları yardımıyla kişilik özellikleri ve hedonik tüketim alt boyutları arasındaki ilişkiler açıklanmaya çalışılmıştır. Katılımcıların yaş, cinsiyet ve eğitim gibi diğer demografik değişkenlere hipotezlerde yer verilmemiş bu veriler bilgi amacıyla sunulmuştur.

Araştırma sonuçları, beş faktör kişilik özelliklerinin hedonik alışveriş boyutları ile çeşitli yönlerde ilişkili olduğunu göstermektedir. Bu araştırmadan elde edilen sonuçlar işletmelerin müşterilerinin kişilik özelliklerini doğru şekilde belirlemesinin, alışverişlerinde sadece faydacı davranmayan aynı zamanda alışveriş deneyimden haz ve mutluluk elde etmenin peşinde olan müşterilerinin de ihtiyaç ve beklentilerini karşılamalarının rekabetçi avantaj sağlayabileceğini göstermektedir. İşletmeler hedonizm odağında değişen tüketim ihtiyaçlarına cevap verebilecektir. Gelecekte yapılacak çalışmalarda demografik verilerinde karşılaştırmalı analizlere dahil edilmesi konu ile ilgili daha spesifik sonuçlar elde edilmesini sağlayacaktır. 
A. Solunoğlu - A. Nalçacı İkiz 12/3 (2020) 2344-2361

\section{Kaynakça}

Allison, P. D. (1999). Multiple regression: A primer. Pine Forge Press.

Arı, B. (2012). Hedonizm, medeniyet kavramı ve etik üzerine https://bilalari.files.wordpress.com/2012/09/hedonizmmedeniyet-ve-etik c3bczerine.pdf (15 Ocak 2020).

Arnold, M., J. and Reynolds, K., E. (2003). Hedonic shopping motivations. Journal of Retailing 79, 77-95.

Avello, M., Gavilán, D., Blasco,F., and Abril, C. (2010). Hedonic buying motivation and timestyle. what makes hurried women shoppers tick. The International Journal of Management and Business, 1,1.

Babin, B. J., Darden, W. R. and Griffin, M. (1994) Work and/or fun: Measuring hedonic and utilitarian shopping value, Journal of Consumer Research, 20(4), 644-656.

Bandura, A. (1999). Social cognitive theory of personality. In PervinL. A., and John O. P. (Eds.), Handbook of personality: Theory and research (2nd ed., pp. 154-196). New York, NY: The Guildford Press.

Bauman, Z. (1997). Postmodernizm ve Hoşnutsuzlukları, Ayrıntı Yayınları, Çev. İsmail Türkmen, İstanbul.

Bircan, İ., Ülker, H. İ., Güneş, G., Karakoç, G., ve Poyraz, Z. (2010). Tourism destination sustainability and non-governmental organizations (ngo's): a case study of Beypazarı. Turkey Journal of Educational Travel, $1(1), 17-32$.

Burger, J. M. (2006). Kişilik. (İ. D. Erguvan Sarığlu, Çev.). İstanbul: Kaknüs Yayınları.

Büyüköztürk, Ş. (2002). Veri analizi el kitabı. Ankara: Pegem Yayıncılık.

Cüceloğlu, D. (1999). İnsan ve davranışı. İstanbul: Remzi Kitabevi.

Deniz, A., ve Erciş, A. (2010). Kişilik özellikleri, hedonik ve rasyonel fayda, marka duygusu ve marka bağlllı̆̆1 arasındaki ilişkilerin belirlenmesine yönelik bir araştırma. Atatürk Üniversitesi İktisadi ve İdari Bilimler Dergisi, 24(2), 141-165.

Doğrul, Ü. (2012). Elektronik alı̧̧veriş davranışında faydacı ve hedonik güdülerin etkisi. Sosyal ve Beşeri Bilimler Dergisi. 4(1), 1309-8012.

Fettahlığlu, H. S., Yıldız, A. ve Birin, C. (2014). Hedonik tüketim davranışları: Kahramanmaraş Sütçü İmam Üniversitesi ve Adıyaman Üniversitesi öğrencilerinin hedonik alışveriş davranışlarında demografik faktörlerin etkisinin karşılaştırmalı olarak analizi. The Journal of Academic Social Science Studies. 27, 307331.

Flynn, L.R. and Goldsmith, R.E.; (2015). Hi, my name is Pat and I am both extraverted and a market Maven: An update and extension of research on Market Mavenism and The Big Five Personality Scale. In Proceedings of the Association of Marketing Theory \& Practice, Savannah, Georgia, 26 March 2015.

Girgin, B. (2007). Beş faktör kişilik modelinin işyerinde duygusal tacize (mobbing) etkileri. Yüksek Lisans Tezi. Dumlupınar Üniversitesi Sosyal Bilimler Enstitüsü. Kütahya.

Goldberg, L., R. (1992). The development of markers for the big-five factor structure. Psychological Assessment, $4(1), 26-42$.

Goldsmith, R. (2016). The big five, happiness, and shopping. Journal of Retailing and Consumer Services, 31, 5261.

Guido, G. (2006). Shopping motives, big five factors, and the hedonic/utilitarian shopping value: an integration and factorial study. Innovative Marketing, 2(2), 57-67.

Gürel,N. (2011). Kişilik psikolojisi, önyargının psikolojisi ve kamuoyu: Gordon Allport ve Walter Lippmann'ın görüşleri çeçevesinde bir değerlendirme. Ankyra: Ankara Üniversitesi Sosyal Bilimler Enstitüsü Dergisi, 2(2), 101-134.

Hair, J. F. Jr., Bush, R. P., and Ortnau, D. J. (2003). Marketing research: within a changing information environment, The McGraw-Hill/Irwin, Second Editon. 
A. Solunoğlu - A. Nalçacı İkiz 12/3 (2020) 2344-2361

Hatipler, M. (2017), Postmodernizm, tüketim, popüler kültür ve sosyal medya. Bilgi Sosyal Bilimler Dergisi, ( 1), 32-50.

Holbrook M., B. and Hirschman, E., C. (1982). Hedonic consumption: emerging concepts, methods and propositions. Journal of Marketing, 46(3), 92-101.

Holbrook M., B. and Hirschman, E., C. (1982). The experiential aspects of consumption: consumer fantasies, feelings, and fun. Journal of Consumer Research, 9(2). 132-140.

John, O. P., and Srivastava, S. (1999). The big-five trait taxonomy: history, measurement, and theoretical perspectives. University of California, Berkeley.

John, O. P., Donahue, E. M., and Kentle, R. L. (1991). The big five inventory--versions $4 a$ and 54. Berkeley, CA: University of California, Berkeley, Institute of Personality and Social Research.

John, O. P., Naumann, L. P., and Soto, C. J. (2008). Paradigm shift to the integrative Big Five trait taxonomy: History, measurement, and conceptual issues. In O. P. John, R. W. Robins, \& L. A. Pervin (Eds.), Handbook of personality: Theory and research (114-158). New York, NY: Guilford Press.

Kalaycı, Ş. (2006). Faktör analizi. spss uygulamalı çok değişkenli istatistik teknikleri, Ankara: Asil Yayın Dağıtım.

Kalaycı, Ş. (2009). SPSS uygulamalı çok değişkenli istatistik teknikleri, Ankara: Asil Yayın Dağıtım.

Karaman, N. G., Dogan, T. ve Coban, A. E. (2010). A study to adapt the big five inventory to Turkish. Procedia Social and Behavioral Science, 2, 2357-2359.

Kavut, S. (2018). Karen horney ve nevrotik kişilik üzerine bir araştırma: Blue Jasmine örneği. Uluslararası Sosyal Araştırmalar Dergisi, 11 (55), 512-524.

Kozak, M. (2015). Bilimsel araştırma tasarım, yazım ve yayım teknikleri. Ankara: Detay.

Larsen, R. J., and Buss, D. M. (2010). Personality psychology: domains of knowledge about human nature. London, England: McGraw Hill.

McCrae, R. R., and John, O. P. (1992). An introduction to the five-factor model and itsapplications. Journal of Personality, 60(2), 175-215.

McCrae, R. R., and Costa, P. T.Jr. (1999). A five factor theory of personality. In PervinL. A., \& JohnO. P. (Eds.), Handbook of personality: Theory and research (2nd ed., pp. 139-153). New York, NY: The Guildford Press.

Odabaşı, Y. (2017). Tüketim kültürü, yetinen toplumdan tüketen topluma. Aura Kitapları. İstanbul.

Osmanlı, U. ve Kaya, S. (2014). Püritanizm'den Hedonizm'e Değişen Boş Zaman Kavramı. Hacettepe Üniversitesi Sosyolojik Araştırmalar E-Dergisi. Erişim: http://w w w . d e r g i . h a c e t t e p e . e d u . t r / $\mathrm{m}$ a k a l e l e r /PrutanizmdenHedonizmeDegisenBosZamanKavrami.pdf.

Özcan, B. (2011). Hedonizm ve kimlik temeline dayalı postmodern tüketim yaklaşımı. Istanbul Journal of Sociological Studies, 1(35), 119-130.

Schmitt, D. P., Allik, J., McRae, R. R., and Benet-Martinez, V. (2007). The geographical distribution of Big Five personality traits: Patterns and profiles of human self-description across 56 nations. Journal of CrossCultural Psychology, 38(2), 173-212.

Somer, O., Korkmaz, M. ve Tatar, A. (2002). Beş faktör kişilik envanteri'nin geliştirilmesi-1: ölçek ve alt ölçeklerin oluşturulması. Türk Psikoloji Dergisi, 17 (49), 21 - 33.

Sönmez, A. (2014), Platon'un Protagoras'ında haz anlayışı üzerine bir inceleme, Ankara Üniversitesi Dil ve TarihCoğrafya Fakültesi Dergisi, 54, 1-20.

Steenkamp, J.-B.E.M., and Maydeu-Olivares, A., (2015). Stability and change in consumer traits: evidence from a 12-year longitudinal study, 2002-2013. J. Mark. Res. 52 (3), 287-308.

Tabachnick, B. G., Fidell, L. S., and Ullman, J. B. (2007). Using multivariate statistics (Vol. 5). Boston, MA: Pearson

Taymur, İ. ve Türkçapar M. H. (2012). Kişilik: tanımı, sınıflaması ve değerlendirmesi. psikiyatride güncel yaklaşımlar, Current Approaches in Psychiatry, 4(2), 154-177. 


\section{A. Solunoğlu - A. Nalçacı İkiz 12/3 (2020) 2344-2361}

www.tdk.gov.tr Erişim tarihi: 20/03/2020

Türk, Z. (2018). Hedonik ve faydacı tüketim eğiliminin plansız satın alma davranışı üzerindeki etkisi: bir araştırma, OPUS Uluslararası Toplum Araştırmaları Dergisi, 9(16), 853-878.

Yıldız Turan, E. (2015). İlkçağ felsefesinde faydacılığın temelleri. Atatürk İletişim Dergisi , (8), 249-258.

Yücedağ, K., İ. (2005). Tüketici davranışı, insana özgü ihtiyaçlar ve hedonik tüketim. Yüksek Lisans Tezi. Adnan Menderes Üniversitesi Sosyal Bilimler Enstitüsü. Aydın. 